\title{
頸䯣損傷者の起立性低血圧と持久力に対する メチル硫酸アメジニウムの効果
}

\author{
逢坂悟郎*,** 原 泰久* 来栖昌朗* \\ 高田正三* 藤田久夫* 越智隆弘**
}

\section{Effect of Amezinium Metilsulfate on Orthostatic Hypotension and Physical Fitness in Cervical Cord Injuries}

\author{
Goro Ohsaka, ${ }^{*} * *$ Yasuhisa Hara, ${ }^{*}$ Masarou Kurusu, ${ }^{*}$ \\ Syozou Takada, ${ }^{*}$ Hisao Fujita, ${ }^{*}$ Takahiro OCHI ${ }^{* *}$
}

\begin{abstract}
The purpose of this study is to evaluate the effect of amezinium metilsulfate (amezinium) on orthostatic hypotension and physical fitness in cervical cord injuries. Eight men with clinically complete tetraplegia (mean age of 21.8 years, mean period after injury of 3.5 years) were administrated amezinium $(10 \mathrm{mg} /$ day $)$ orally every day for two months. Head up tilt test, measurement of $\mathrm{CV}_{\mathrm{R}-\mathrm{R}}$, exercise testing using respiratory gas analysis with arm ergometer, and 12-minute performance test were performed before and at two months after administration. The average minimum level of systolic blood pressure (SBP) with head up tilting rose significantly from $57.4 \mathrm{mmHg}$ to $79.0 \mathrm{mmHg}$. On the other hand SBP at rest, which usually shows maximum levels during this test, remained stable. Therefore, decrease in SBP with tilting was reduced after administration. The results of measurement of $\mathrm{CV}_{\mathrm{R}-\mathrm{R}}$ showed increase in 3 patients, decrease in 2 patients, and no change in 3 patients. Mean \%peak $\dot{\mathrm{VO}}_{2}$ increased significantly from $37.5 \%$ to $42.0 \%$, and mean $\%$ peak HR rose significantly from $55.4 \%$ to $66.2 \%$ in exercise testing. The mean distance was prolonged significantly from $714.1 \mathrm{~m}$ to $854.3 \mathrm{~m}$ in the 12 -minute test. These results indicate that amezinium has a good effect on the improvement of orthostatic hypotension and physical fitness in cervical cord injuries. (Jpn J Rehabil Med 1997 ; 34 : 226-229)
\end{abstract}

要 旨：頸髄損傷者（以下，頸損）8名にメチル硫酸アメジニウム（以下アメジニウム）を 投与し, 投与前後の起立試験， $\mathrm{CV}_{\mathrm{R}-\mathrm{R}}$ 值測定，基礎体力測定，12 分間走を行い，起立性低血 圧，持久力の改善を観察した。起立試験では，立位負荷時の収縮期圧最低值の有意な上昇と収 縮期圧下降度の縮小を認め, 基礎体力測定では, \% $\mathrm{VO}_{2 \text { peak }}$ ・\% $\mathrm{HR}_{\text {peak }}$ が有意に増加し, 12 分間走でも, 走行距離が有意に延長したが, 改善を示さない症例も少数あった。 $\mathrm{CV}_{\mathrm{R}-\mathrm{R}}$ 值は, 一定の変化を認めなかった。以上より，アメジニウムは，大部分の頸損の起立性低血压，持久 力の改善に有効であると考えられた。(リ八医学 $1997 ; 34: 226-229$ )

Key words : 頸髄損傷（cervical cord injury），起立性低血圧（orthostatic hypotension）, メチル硫酸アメジニウム (amezinium metilsulfate), 基礎体力 (physical fitness)

1996 年 4 月 18 日受付, 1996 年 11 月 11 日受理

*兵庫県立総合リハビリテーションセンター/テ 651-21 兵庫県神戸市西区曙町 1070

Hyogo Rehabilitation Center

** 大阪大学医学部整形外科/ 5565 大阪附吹田市山田丘 2-2

Department of Orthopaedic Surgery, Osaka University 
はじめに

頸髄損傷者（以下，頸損と略す）は四肢体幹の運 動, 知覚麻渒のみでなく, 起立性低血圧・うつ熱など 多彩な自律神経障害を合併しており，これらがリハビ リテーションの阻害因子になることが多い，歷史的に は頸損の起立性低血圧に対し，薬物療法，物理療法な ど様々な治療法が試みられてきたが，いずれも著効を 得るには至らなかった ${ }^{1,2)}$.

我々はこれまで，著しい起立性低血圧のために訓練 効果が上がらずにいる慢性期頸損に対し，塩酸エチレ フリン，メチル酸ジヒドロエルゴタミンなどの交感神 経刺激剤による薬物療法を試みてきたが，満足いく結 果を得られないでいた。 そのなかで，メチル硫酸アメ ジニウム (以下，アメジニウムと略す) を投与したと ころ, 起立性低血圧の著しい改善を認め, 2 次的に訓 練効果が上がった症例を数例経験した。文献的には， Shy-Drager 症候群や自律神経ニューロパシーにみら れる神経原性起立性低血圧に対するアメジニウムの有 効性はすでに報告されているが3)，頸損に合併する起 立性低血圧に対するアメジニウムの効果に関する報告 は，我々が渉猟しえた範囲では国際的にも皆無であ る，そこで，今回，自律神経検査，基礎体力測定など を用いてアメジニウムが頸損の起立性低血圧や持久力 に及湾す影響を検討した。

\section{対象}

対象は，頸損 8 名で，年齢は $20 \sim 31$ 歳（平均 21.8 歳)，受傷よりの経過期間は $1.3 \sim 7.6$ 年 (平均 3.5 年)，すべて男性である。Zancolli 分類では C 6 B 1 から C 7 A で，Frankel 分類ではすべて A の完全麻 痺である。

これらの症例に，アメジニウム $10 \mathrm{mg}$ を毎朝経口 投与し，投与前後の検査結果を検討した。観察期間 は，2 か月である．観察期間中の訓練プログラムは投 与前と大きな変更を加えないこととし，理学療法，作 業療法，体育訓練などを継続した。なお，起立訓練は 行わなかった，また，投薬に先立ち，全症例に対しア メジニウムの作用機序及び効果，予想される副作用に ついての説明を行い，同意を得た。
方法

\section{1. 自律神経検査}

今回我々は手指にて 1 心拍ごとに血圧，脈拍の測定 可能な Finapres BP Monitor 2300 (Ohmeda 社) を 用い，この情報をコンピューターで処理することによ $\eta$ ，交感神経機能，副交感神経機能の評価を行った (本法が心電計による従来法と高い一致を示すことは すでに報告した少)。

\section{1）ヘッドアップ・ティルト試験}

交感神経反射機能を検査する目的で，約 15 分間の 仰臥位安静の後, tilt table をすばやく 70 度まで挙上 し，約 10 分間，血圧・脈拍を 30 秒ごとに測定した5).

\section{2）呼吸性不整脈検査}

副交感神経の緊張度を測定する目的で，1 分間に 6 回の深呼吸負荷を行い，心電図 R-R 間隔変動係数 $\left(\mathrm{CV}_{\mathrm{R}-\mathrm{R}}\right)$ を測定した ${ }^{5,6)}$.

\section{2. 基礎体力測定}

アームエルゴメーター（ロード社，アンギオWLP300）を用い，60 rpmで 1 分間に $5 \mathrm{~W}$ のランプ漸増 法による運動負荷にて呼気ガス分析を行った。呼気ガ ス分析機（ミナト社， RM-300）にて最大酸素摂取量 を測定し，同時に，心電計（フクダ社，ML 5000）に て最大心拍数を測定した。

\section{3. 持久力テスト（12 分間走）}

ロードマシーン（トーヨー社）を用いて，一定の抵 抗を加え，12 分間での走行距離を測定し，持久力の 指標とした。なお，統計学的処理には，Wilcoxon の 順位検定を用いた。

\section{結果}

\section{1）ヘッドアップ・ティルト試験}

立位負荷後の収縮期血圧の最低值は，アメジニウム 投与前, 平均 $57.4 \mathrm{mmHg}$ であったが, 投与後 2 か月 にて平均 $79.0 \mathrm{mmHg}$ となり，有意な上昇を示した $(p<0.05)$ (図 $1 \mathrm{~A})$. 同時に，めまい，耳鳴りなどの 臨床症状も改善した。

立位負荷による収縮期血圧下降の程度は，投与前， 平均 $61.3 \mathrm{mmHg}$ であったが，投与後 2 か月にて平均 $39.5 \mathrm{mmHg}$ となり, 有意差は認めないものの，減少 傾向を示した（図 1 B).

個別にみると症例 1 から 6 において，収縮期血圧の 最低值の上昇と収縮期血圧下降の程度の減少を認め, 
(A) ヘッドアップ・ティルト試験

収縮期血圧の最低值

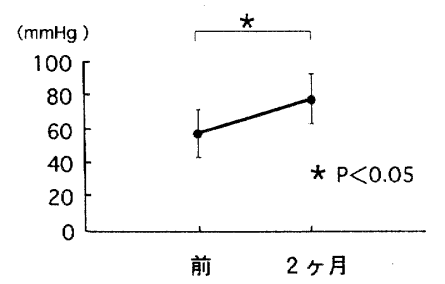

（D）基礎体力測定

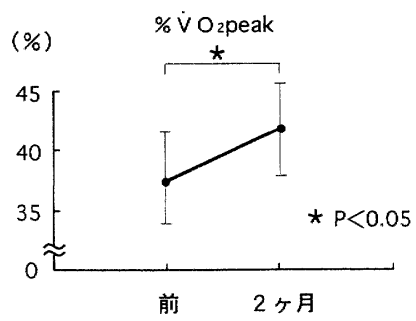

(B) ヘッドアップ・ティルト試験 収蛨期血圧下降の程度

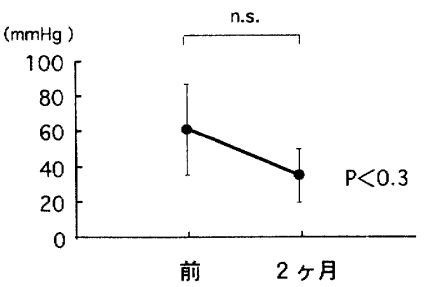

（E）基礎体力測定

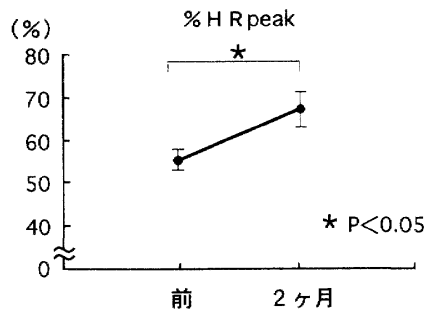

(C) 心電図R-R間隔变動係数 $\left(C V_{R-R}\right)$

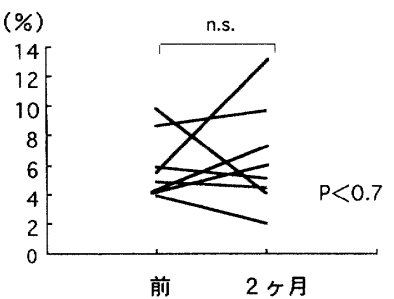

(F) 12 分間走

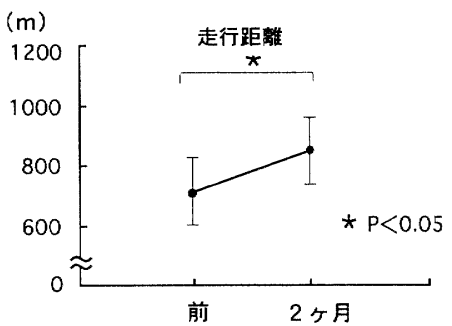

図 1 ヘッドアップ・ティルト試験 $(\mathrm{A}),(\mathrm{B}), \mathrm{CV}_{\mathrm{R}-\mathrm{R}}(\mathrm{C})$, 基礎体力測定 $(\mathrm{D}),(\mathrm{E}), 12$ 分間走 $(\mathrm{F})$ の結果

表 1 アメジニウムに対する反応のまとめ（太線内は非改善項目）

\begin{tabular}{|c|c|c|c|c|c|c|c|c|}
\hline \multirow{3}{*}{ 症例 } & \multicolumn{4}{|c|}{ ヘッドアップ・ティルト試験 } & \multicolumn{4}{|c|}{ 基礎体力測定 } \\
\hline & \multicolumn{2}{|c|}{ 収縮期圧最低值 (mmHg) } & \multicolumn{2}{|c|}{ 収縮期压低下度 (mmHg) } & \multirow{2}{*}{$\begin{array}{c}\% \dot{\mathrm{VO}}_{2 \text { peak }} \\
(\%)\end{array}$} & \multirow{2}{*}{$\begin{array}{c}\% \mathrm{HR}_{\text {peak }} \\
(\%)\end{array}$} & \multirow{2}{*}{$\begin{array}{c}12 \text { 分間走 } \\
(\mathrm{m})\end{array}$} & \multirow{2}{*}{$\begin{array}{c}\mathrm{CV}_{\mathrm{R}-\mathrm{R}} \\
(\%)\end{array}$} \\
\hline & 投与前 $\rightarrow$ 投与後 & 前後差 & 投与前 $\rightarrow$ 投与後 & 前後差 & & & & \\
\hline 1 & $50 \rightarrow 85$ & +35 & $111 \rightarrow 30$ & -81 & +10.0 & +17.4 & +246 & -2.0 \\
\hline 2 & $49 \rightarrow 70$ & +21 & $56 \rightarrow 32$ & -24 & +8.9 & +14.5 & +101 & +2.0 \\
\hline 3 & $44 \rightarrow 99$ & +55 & $62 \rightarrow 29$ & -33 & +1.6 & +16.3 & +258 & +2.8 \\
\hline 4 & $77 \rightarrow 92$ & +15 & $50 \rightarrow 29$ & -21 & +9.6 & +17.7 & +180 & +1.1 \\
\hline 5 & $64 \rightarrow 80$ & +16 & $49 \rightarrow 29$ & -20 & +4.8 & +18.5 & +121 & -0.8 \\
\hline 6 & $45 \rightarrow 80$ & +35 & $83 \rightarrow 33$ & -50 & -0.8 & -3.2 & +130 & -0.4 \\
\hline 7 & $43 \rightarrow 46$ & +3 & $46 \rightarrow 80$ & +34 & +6.8 & +10.2 & +179 & -5.7 \\
\hline 8 & $87 \rightarrow 80$ & -7 & $33 \rightarrow 55$ & +22 & -4.6 & -5.3 & -94 & +7.5 \\
\hline
\end{tabular}

起立性低血压の改善をみた。しかし，症例 7,8では 収縮期血圧の最低值は著変を認めず，収縮期血圧下降 の程度が，投与前に比しそれぞれ $34,22 \mathrm{mmHg}$ 増大 し増悪傾向を示した（表 1).

\section{2）呼吸性不整脈検査}

心電図 R-R 間隔変動係数 $\left(C V_{R-R}\right)$ の投与前後の 変化に打いては，2\%以上増加した者 3 例, $2 \%$ 以上減 少した者 2 例, 著変のない者 3 例と反応が分かれた が, 臨床症状の変化, アメジニウムの効果との関連は 認めなかった（図 1C).

\section{3）基礎体力測定}

呼気ガス分析では, 最大酸素摂取量を予測值の百分 率で示す\% $\mathrm{VO}_{2 \text { peak }}$ は, 投与前, 平均 $37.5 \%$ あ゙あた が, 投与後 2 か月にて $42.0 \%$ と有意な上昇を示した $(p<0.05)$ (図 1 D).

最高脈拍数を予測值の百分率で示す\%HR 投与前，平均 $55.4 \%$ であったが，投与後 2 か月にて $66.2 \%$ と有意な上昇を示した $(p<0.05)$ (図 $1 \mathrm{E}$ ). 個別にみると症例 1 \% 及び症例 7 で，\% $\% \mathrm{VO}_{2 \text { peak }} \%$ $\mathrm{HR}_{\text {peak }}$ ともに増加を示したが, 症例 6,8 ではともに 減少した (表 1).

\section{4) 持久力テスト}

12 分間走では, 投与前, 平均 $714.1 \mathrm{~m}$ であったが, 投与後 2 かににて $854.3 \mathrm{~m}$ と有意な延長を示した $(p<0.05)$ (図 $1 \mathrm{~F})$. しかし, ヘッドアップ・ティル 卜試験，基礎体力測定でともに改善がみられなかった 症例 8 では, 投与前 $919 \mathrm{~m}$ から, 投与後 2 か月で 825 $\mathrm{m}$ と走行距離の短縮を認めた. 


\section{考 察}

アメジニウムは，ノルアドレナリンと競合して交感 神経終末に取り込まれ，ノルアドレナリンの再取り达 みを抑制すると同時に交感神経終末においてノルアド レナリンの不活性化を抑制し，内因性ノルアドレナリ ンの利用率を増加させ, 間接的に交感神経機能を元進 させる．血管に対する $\alpha_{1}$ 受容体刺激作用と心蔵に対 する $\beta_{1}$ 受容体刺激作用を有し，末梢血管抵抗及び心 拍出量を増加させて血圧を上昇させるとされる7).

今回の研究では，アメジニウム投与で，8例中 6 例 (75\%) にヘッドアップ・ティルト試験での改善をみ たことより，アメジニウムが頸損の起立性低血圧の改 善に有効であると考えられた. 文献的にはこれまで頸 損の起立性低血圧に対し, 腹帯等の物理療法, $5 \%$ $\mathrm{CO}_{2}$ 吸入, 痤縮の誘発, 膀胱の吒打など様々な治療 法が試みられてきたが，いずれも著しい改善をみるに は至らなかった ${ }^{1,2)}$.また, 薬物療法では, エピネフ リン ${ }^{8)}$, エフェドリン ${ }^{9)}$ にいての報告があるが満足 な効果を得るには至らず, 現在, 臨床的には投与され ていない. 最近では L-threo-3,4-dihydroxyphenylserine(L-DOPS)の効果に関する報告があったが10,11), いずれも胸髄損傷者を対象とした 1 例報告であり，今 後の多症例の頸損による検討を要すると思われる。ま た，先に述べたようにアメジニウムの頸損の起立性低 血圧に対する効果に関する報告はこれまで皆無であ る. 今後, アメジニウムが多施設で使用され, その効 果が検証されれば，頸損の起立性低血圧に対する治療 を大きく前進させる可能性があるものと考える.

今回，アメジニウムの投与により起立性低血圧の改 善のみならず, \% $\% \mathrm{VO}_{2 \text { peak }}$ ・ 12 分間走で有意な上昇・ 延長を認めた。これは, 運動時に $\alpha_{1}$ 受容体刺激作用 により末梢血管収縮力が強まるとともに， $\beta_{1}$ 受容体 刺激作用により脈拍が上昇することで心拍出量が増加 し,これらの相乗効果により運動時の血圧維持が可能 となったことが一因であると思われる. そして, これ により，これまで起立性低血圧のために訓練が持続で きなかった頸損が，投与後，訓練を十分に継続できる ようになり二次的に訓練効果が現れたものと考える. この結果は,アメジニウムが頸損の交感神経障害を改 善することにより, 体力, 持久力の向上にも寄与する 可能性を示し, 頸損のリハビリテーションを進める上 で注目すべき事実である。
しかし，今回の 8 症例がすべて改善を示したわけで はなく, 症例 6 , 症例 8 のように\% HR peak なく， $\beta_{1}$ 受容体刺激作用が現れない例もある。また， 症例 8 はアメジニウムにより全般に悪化を認め, 同様 な完全麻痺を呈する頸損であってもアメジニウムに対 する反応性は多様であることを示した。

今後, 症例数を増やすことにより, 頸損の自律神経 障害に対するアメジニウムの適応条件の確立と, 無効 例に対する治療法の検討を行いたいと考える。

本論文の要旨は第 32 回日本リハビリテーション医学会 学術集会にて発表した。

\section{文献}

1) Figoni SF : Cardiovascular and haemodynamic responses to tilting and to standing in tetraplegic patients: A Review. Paraplegia 1984 ; 22 : 99-109

2) Gonzalez F, Chang JY, Banovac K, Messina D, Martinez-Arizala A, Kelley RE: Autoregulation of cerebral blood flow in patients with orthostatic hypotension after spinal cord injury. Paraplegia $1991 ; 29: 1-7$

3）平山恵造, 北 耕平, 宇尾野公義, 濱口勝彦, 高橋 昭, 岡鳴 透: 間接型交感神経作動薬 amezinium metilsulfate の神経原性起立性低血圧に対する治療効果. 神 内治療 $1989 ; 6$ : 255-265

4）細川晃代, 永田安雄, 谷 洋美, 山本千恵子, 原 泰久: Finapres 法を用いた自律神経機能検査. 第 34 回近畿 臨床衛生検查学会講演集 $1995 ; 34: 159$

5) 日本自律神経学会編：自律神経機能検查. 第 1 版, 文光 堂, 東京, 1992; pp 10-13, 21-37

6）藤本順子, 弘田明成, 畑美智子, 近藤まみ子：心電図 $\mathrm{R}-\mathrm{R}$ 間隔の変動を用いた自律神経機能検査の正常参考 值および標準予測式. 糖㽷病 $1987 ; 30$ : 167-173

7) Lenke D, Grics J, Kretzschmar R : Pharmacology of amezinium, a novel antihypotensive drug.: III. Studies on the mechanism of action. Arzneim Forsch 1980; 31: 1558-1565

8) Scheinberg D: Resurgence of vasomotor adaptation to tilting after epinephrine. J Tenn Med Assoc $1976 ; 69: 724$

9) Claus-Walker J, Halstead LS : Autonomic drugs in spinal cord injury: temporal prescription profile. Arch Phys Med 1978; 59: 363-367

10）小田嶋奈津，古川哲雄，塚越廣：L-threo-3,4dihydroxyphenylserine (L-DOPS) の内服により起 立性低血圧の改善を認めた高位胸髄損傷の1例. 神内 治療 $1991 ; 8$ : 637-641

11) Muneta $S$, Iwata $T$, Hiwada $K$, Murakami $E$, Sato $\mathrm{Y}$, Imamura $\mathrm{Y}$ : Effect of L-threo-3, 4-dihydroxyphenylserine on orthostatic hypotension in a patient with spinal cord injury. Jpn Circ J 1992 ; 56 : 243-247 